\title{
Inhibitory effects of anticardiolipin antibodies on lymphocyte proliferation and neutrophil phagocytosis
}

\author{
Chia-Li Yu, Kuang-Hui Sun, Chang-Youh Tsai, Soo-Ray Wang
}

\begin{abstract}
Anticardiolipin antibodies purified from serum from patients with systemic lupus erythematosus (SLE) by cardiolipin micelles were studied for their effects on lymphocytes and neutrophils. At a concentration of $160 \mu \mathrm{g} / \mathrm{ml}$ they markedly suppressed the $\left[{ }^{3} \mathbf{H}\right.$ ]thymidine incorporation of mononuclear cells stimulated by phytohaemagglutinin (4.9 (SEM 1.9\%) of the control) and pokeweed mitogen (26.7 (10.5\%) of the control). In addition, anticardiolipin antibodies changed the cell cycle of phytohaemagglutinin stimulated lymphocytes such that the $S$ and $G 2+M$ phases were significantly diminished $(\mathbf{G 0} / \mathbf{G 1}=$ $64.62 \%, S=20.59 \%, G 2+M=14.78 \%$ in the presence of normal human IgG $v$ G0/G1 $=$ $86.07 \%, S=10.32 \%, G 2+M=3.59 \%$ in the presence of anticardiolipin antibodies). The suppression of lymphocyte proliferation by anticardiolipin antibodies was shown not to be caused by an alteration of $T$ cell subpopulations. However, the interleukin 2 receptors on the cell surface and the soluble interleukin 2 receptors in the supernatant of phytohaemagglutinin stimulated mononuclear cells were decreased in the presence of anticardiolipin antibodies. On the other hand, the phagocytic activity of neutrophils was $40 \%$ inhibited at a higher concentration of anticardiolipin antibodies $(300 \mu \mathrm{g} / \mathrm{ml})$ through suppression of $\mathrm{C} 3 \mathrm{~b} / \mathrm{C} 4 \mathrm{~b}$ and Fc receptors on polymorphonuclear leucocytes. These results suggest that anticardiolipin antibodies exert inhibitory effects on both lymphocytes and phagocytes in addition to the coagulation cascade. These newly found activities of anticardiolipin antibodies were mediated by the non-specific membranotropic property of the antibodies.
\end{abstract} to be associated with a broad spectrum of patients with systemic lupus erythematosus negatively charged phospholipids in the coagulation cascade and plasma membrane they that anticardiolipin antibodies purified by cardiolipin-cholesterol liposome from the serum of a patient with infectious mononucleosis reacted with the membrane of lectin activated lymphocytes and certain cell lines. ${ }^{11}$ These results suggest that activation of membrane is mandatory for the expression of binding epitopes with anticardiolipin antibodies. Thus, possibly, anticardiolipin antibodies may exert certain biological effects on the activated cells through non-specific binding to the cell membrane as long as the epitopes are exposed. However, the biological activity of anticardiolipin antibodies, other than anticoagulation, has never been reported. In this study anticardiolipin antibodies were partially purified from SLE serum by cardiolipin micelles and their effects on the functions of normal human lymphocytes and phagocytes were investigated.

\section{Patients and methods}

PATIENTS' SERUM SAMPLES

Serum samples from patients fulfilling four or more of the 1982 revised American Rheumatism Association criteria for the classification of SLE $^{12}$ were screened for the presence of anticardiolipin antibodies by enzyme linked immunosorbent assay (ELISA). Only those samples with an absorbance at $410 \mathrm{~nm}$ higher than 0.6 (normal serum $<0.3$ ) were purified further.

PURIFICATION OF ANTICARDIOLIPIN ANTIBODIES WITH CARDIOLIPIN MICELLES

We used the method described by Harris et al, ${ }^{13}$ with some modifications. Briefly, cardiolipin was dissolved in ethanol (Sigma Chemicals, St Louis, MO, USA) and evaporated in a vacuum oven to dryness. Cardiolipin micelles were created by adding phosphate buffered saline solution, $\mathrm{pH} 7 \cdot 2$, to dried cardiolipin with vigorous agitation in vortex. Serum $(10 \mathrm{ml})$ containing anticardiolipin antibodies was then mixed with $5 \mathrm{ml}$ of micelles $(3 \mathrm{mg} / \mathrm{ml})$ and incubated at $37^{\circ} \mathrm{C}$ for one hour and at $4^{\circ} \mathrm{C}$ overnight with constant shaking. After incubation the mixture was spun at $27000 \mathrm{~g}$ for 15 minutes. The pellet was suspended in $30 \mathrm{ml}$ phosphate buffered saline, $\mathrm{pH} 7 \cdot 2$, and centrifuged again at $27000 \mathrm{~g}$ for 15 minutes. Washing was repeated three times to remove the nonbound proteins. Finally, the pellet was suspended in $2 \mathrm{ml}$ of $1 \mathrm{M} \mathrm{NaI}$ and the suspension incubated at room temperature for 60 minutes to interrupt the linkage between antibodies and micelles. The suspension was again centrifuged at $27000 \mathrm{~g}$ for 15 minutes. On this occasion the
Anticardiolipin antibodies have been reported disease, such as deep vein thrombosis, coronary artery occlusion, pulmonary hypertension, neurological disorders, and habitual abortion in (SLE). ${ }^{1-6}$ As these antibodies can bind to may cause paradoxical hypercoagulability, ${ }^{7}$ thrombocytopenia, ${ }^{8}$ and haemolytic anaemia. Khamashta et al showed that purified anticardiolipin antibodies could stick to freezethawed platelets and red cells but not to untreated cells. ${ }^{10}$ Misra et al further showed
201 Section 2, Shih-Pai Road, Taipei, Taiwan 11217 Republic of China.

Accepted for publication 19 December 1990

Section of Allergy,
Immunology and
Rheumatology,
Department of Medicine,
Veterans General
Hospital, Taipei,
Taiwan
Republic of China
C-L Yu
S-R Wang
School of
Medical Technology,
National Yang-Ming
Medical College,
Taipei, Taiwan,
Republic of China
K-H Sun
Institute of
Clinical Medicine,
National Yang-Ming
Medical College,
Taipei, Taiwan,
Republic of China
C-Y Tsai
Correspondence to:
Dr Chia-Li Yu,
Section of Allergy,
Immunology and
Rheumatology,
Department of Medicine,
Veterans General
Hospital-Taipei,
201 Section 2, Shih-Pai Road,
Taipei, Taiwan 11217,
Republic of China.
Accepted for publication
19 December 1990
Than


micelles floated on the top and the subnatant was removed. The subnatant fraction was then intensively dialysed against phosphate buffered saline, $\mathrm{pH} 7 \cdot 2$, at $4^{\circ} \mathrm{C}$ for 24 hours. Finally, the dialysate was changed to RPMI-1640. The protein concentration of the antibodies was measured by a Bio-Rad protein assay kit (BioRad Laboratories, Richmond, CA, USA) and the purity by $10 \%$ sodium dodecyl sulphatepolyacrylamide gel electrophoresis. The anticardiolipin activity of the antibodies was estimated by an ELISA. ${ }^{14}$

\section{ISOLATION OF MONONUCLEAR CELLS AND POLYMORPHONUCLEAR LEUCOCYTES FROM PERIPHERAL BLOOD}

Heparinised venous blood from normal subjects was mixed with a quarter volume of $2 \%$ dextran solution (mol wt 500000 ) and incubated at $37^{\circ} \mathrm{C}$ for 20 minutes. Supernatant rich in leucocytes was collected and diluted with the same volume of Hanks's balanced salt solution. After centrifugation at $300 \mathrm{~g}$ for 30 minutes over a FicollHypaque cushion (specific gravity 1.077) the mononuclear cells were aspirated from the interphase while polymorphonuclear leucocytes were obtained from the bottom. The purity of the polymorphonuclear leucocytes was greater than $95 \%$ as confirmed by Wright's stain.

\section{MITOGEN INDUCED $\left[{ }^{3} \mathrm{H}\right]$ THYMIDINE}

INCORPORATION IN MONONUCLEAR CELLS

Mononuclear cells $\left(100 \mu \mathrm{l} ; 1 \times 10^{6} / \mathrm{ml}\right)$ were placed in flat bottomed microwells in triplicate. Phytohaemagglutinin $20 \mu \mathrm{l} ; 20 \mu \mathrm{g} / \mathrm{ml}$ ) and 0.08 $\mathrm{ml}$ of anticardiolipin antibodies $(400 \mu \mathrm{g} / \mathrm{ml})$ were added to the wells. In the control wells $0.08 \mathrm{ml}$ of RPMI-1640 or purified human IgG $(400 \mu \mathrm{g} / \mathrm{ml})$ was added instead of anticardiolipin antibodies. Stimulation of $\left[{ }^{3} \mathrm{H}\right]$ thymidine by pokeweed mitogen was carried out as for the phytohaemagglutinin assay except that the concentration of pokeweed mitogen was 100 $\mu \mathrm{g} / \mathrm{ml}$. The mixture was incubated at $37^{\circ} \mathrm{C}$ in $5 \% \mathrm{CO}_{2}-95 \%$ air for 68 hours and then pulsed with $18.5 \mathrm{kBq} \quad$ [methyl- ${ }^{3} \mathrm{H}$ ] thymidine/well (specific activity $248 \mathrm{GBq} / \mathrm{mmol}$; NEN, Boston, USA) at $37^{\circ} \mathrm{C}$ for four hours. The cells were harvested and the radioactivity measured by a beta counter.

\section{CELL CYCLE ANALYSIS OF MITOGEN STIMULATED} MONONUCLEAR CELLS

The mixture of $0.4 \mathrm{ml}$ mononuclear cells $\left(2.25 \times 10^{6} / \mathrm{ml}\right), 0.5 \mathrm{ml}$ anticardiolipin antibodies $(400 \mu \mathrm{g} / \mathrm{ml})$ or human $\mathrm{IgG}(400 \mu \mathrm{g} / \mathrm{ml})$, and $0 \cdot 1$ $\mathrm{ml}$ mitogen (phytohaemagglutinin $20 \mu \mathrm{g} / \mathrm{ml}$ or pokeweed mitogen $100 \mu \mathrm{g} / \mathrm{ml}$ ) in a sterile plastic tube was incubated at $37^{\circ} \mathrm{C}$ in $5 \% \mathrm{CO}_{2}-95 \%$ air for three days. The nuclear DNA was stained with $50 \mu \mathrm{g} / \mathrm{ml}$ of propidium iodide in $0.1 \%$ sodium citrate and $0.2 \%$ Triton $\mathrm{X}-100$. The cell cycle was analysed by EPICS C flow cytometry (Coulter Electronics, Hialeah, Miami, FL, USA). The percentage of each phase in the cell cycle was calculated with the PARA-1 program provided by Coulter Electronics.
DETERMINATION OF T CELL SUBPOPULATIONS AND INTERLEUKIN 2 RECEPTORS

Fluorescent conjugated monoclonal antibodies against $\mathrm{CD} 3, \mathrm{CD} 4, \mathrm{CD} 8$, and interleukin 2 receptor (Coulter Immunology) were used to stain the surface markers of mononuclear cells stimulated with phytohaemagglutinin in the presence of anticardiolipin antibodies or human IgG by flow cytometry.

In addition, the culture supernatants were collected after three days for measurement of soluble interleukin 2 receptors.

The concentration of soluble interleukin 2 receptor in various supernatants was measured by a commercial test kit (AMAC, Westbrook, ME, USA). The sensitivity of the assay was $0 \cdot 2$ fmol. The coefficients of variation of intra and interassays were $5 \cdot 5 \%$ and $11 \cdot 3 \%$ respectively.

\section{MEASUREMENT OF POLYMORPHONUCLEAR \\ LEUCOCYTE PHAGOCYTOSIS}

Fluoresbrit carboxylate microspheres $(0.75 \mu \mathrm{m}$; Polysciences, Warrington, PA, USA) were first opsonised with fresh normal human serum at $37^{\circ} \mathrm{C}$ for 45 minutes. Polymorphonuclear leucocytes $\left(50 \mu \mathrm{l} ; 1.2 \times 10^{7} / \mathrm{ml}\right)$ were incubated with $150 \mu \mathrm{l}$ of anticardiolipin antibodies $(0.4 \mathrm{mg} / \mathrm{ml})$ or human $\operatorname{IgG}(0.4 \mathrm{mg} / \mathrm{ml})$ at $37^{\circ} \mathrm{C}$ for one hour. Opsonised fluorescent beads $\left(10 \mu \mathrm{l} ; 2 \times 10^{9}\right.$ particles $/ \mathrm{ml}$ ) were then added to the mixture and incubated for another hour. The beads which had not undergone phagocytosis were removed after three washes at $300 \mathrm{~g}$ for 10 minutes. The percentage and fluorescence intensity of the polymorphonuclear leucocytes which had taken part in phagocytosis of the beads were determined by EPICS C flow cytometry. ${ }^{15}$

DETERMINATION OF C3b RECEPTORS AND IgG Fc RECEPTORS ON POLYMORPHONUCLEAR

LEUCOCYTES

An indirect immunofluorescence antibody method was used to determine the $\mathrm{C} 3 \mathrm{~b}$ and IgG Fc receptors on polymorphonuclear leucocytes. Monoclonal mouse antihuman $\mathrm{C} 3 \mathrm{~b}$ receptors (Dako, Kakopatts, Denmark) and fluorescein isothiocyanate labelled rabbit antimouse IgG2a antibodies were the primary and secondary antibodies for staining the $\mathrm{C} 3 \mathrm{~b}$ receptors on the polymorphonuclear leucocytes. Heat aggregated $\left(63^{\circ} \mathrm{C}, 45\right.$ minutes) human IgG (250 $\mu \mathrm{g} / \mathrm{ml}$ ) and fluorescein isothiocyanate labelled goat antihuman IgG were the ligand and antibodies for staining the $F c$ receptors on the polymorphonuclear leucocytes. The percentage and fluorescence intensity of these receptors on the polymorphonuclear leucocytes were analysed by flow cytometry at $488 \mathrm{~nm}$.

\section{STATISTICAL ANALYSIS}

Results are expressed as the mean (SEM) for the whole study. Statistical significance was assessed by non-parametric Wilcoxon signed ranks test. 


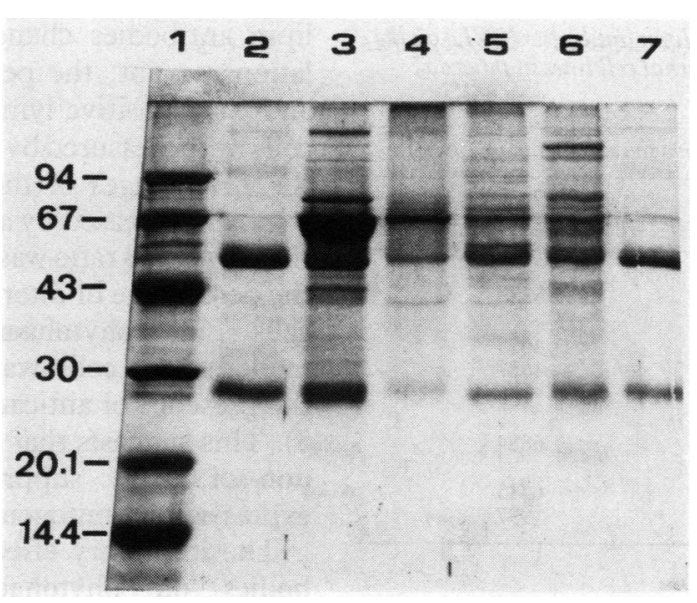

Figure 1 Electrophoretic analysis of molecules bound and unbound with cardiolipin micelles by $10 \%$ sodium dodecyl sulphate-polyacrylamide gel electrophoresis. Lane I= calibration proteins; lane $2=$ human IgG $(40 \mu \mathrm{g})$; lane $3=$ supernatant containing unbound molecules from a normal human serum; lane 4 = supernatant containing bound molecules from an SLE serum; lane $5=$ bound molecules from a normal serum; lane $6=$ affinity purified anti-dsDNA antibodies; lane $7=$ human IgG $(20 \mu g)$

\section{Results}

CARDIOLIPIN BINDING ACTIVITY OF PARTIALLY PURIFIED ANTICARDIOLIPIN ANTIBODIES

Anticardiolipin antibodies purified from SLE sera by cardiolipin micelles contained IgG and albumin as shown by sodium dodecyl sulphatepolyacrylamide gel electrophoresis (fig 1). The cardiolipin binding activity of these antibodies was measured by ELISA. Anticardiolipin antibodies at a protein concentration of $400 \mu \mathrm{g} / \mathrm{ml}$ were equivalent to an absorption of 0.5 at 280 nm. Most of the experiments were carried out at this protein concentration.

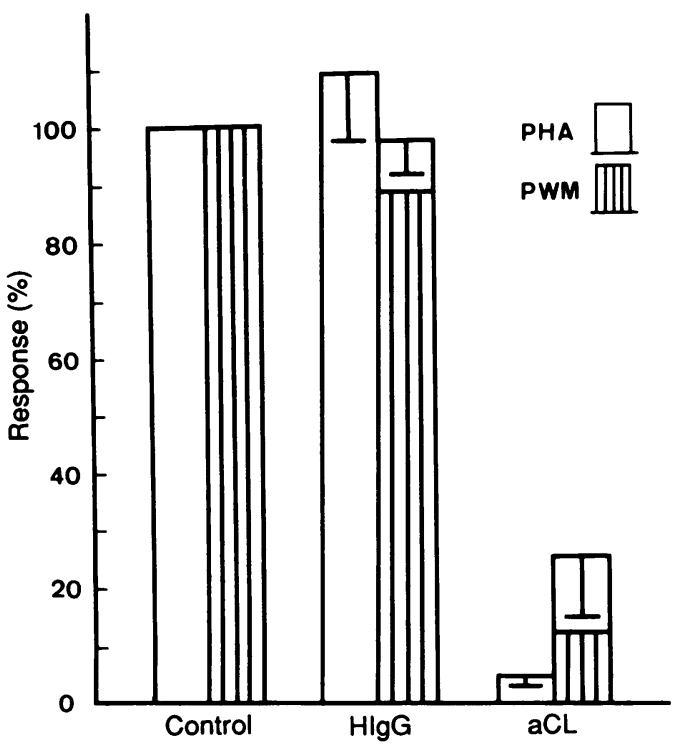

Figure 2 Effects of anticardiolipin antibodies $(a C L)$ on the phytohaemagglutinin (PHA) and pokeweed mitogen (PWM induced $\left[{ }^{3} H\right]$ thymidine incorporation in normal human mononuclear cells in three day cultures. The percentage response represents the counts per minute (cpm) of mitogen stimulated mononuclear cells in the presence of $160 \mathrm{\mu g} / \mathrm{ml}$ of human IgG (HIgG) or anticardiolipin antibodies divided by the cpm of mitogen stimulated mononuclear cells (control).
INHIBITION OF [ $\left[{ }^{3} \mathrm{H}\right]$ THYMIDINE INCORPORATION IN MONONUCLEAR CELLS

Anticardiolipin antibodies, at a final concentration of $160 \mu \mathrm{g} / \mathrm{ml}$, markedly suppressed phytohaemagglutinin and pokeweed mitogen induced $\left[{ }^{3} \mathrm{H}\right]$ thymidine incorporation in normal mononuclear cells (fig 2). This suppression by anticardiolipin antibodies was dependent on dose (fig 3). The antibodies did not change the cell viability even when the concentration was increased to $480 \mu \mathrm{g} / \mathrm{ml}$, as confirmed by a trypan blue dye exclusion test. In an additional experiment the cardiolipin micelles were incubated with $1 \mathrm{M}$ sodium iodide at room temperature for one hour and then treated by the same procedures as in the preparation of antibodies. The supernatant obtained did not change the mitogen response of the mononuclear cells (data not shown). Furthermore, sodium iodide at concentrations ranging from $10^{-2}$ to $10^{-6} \mathrm{~mol} / \mathrm{l}$ did not suppress the mitogen response of mononuclear cells (table 1). In addition to the normal mononuclear cells, anticardiolipin antibodies also suppressed the proliferation of certain cell lines such as WI-L2 (B lymphoma cell) and Jurkat cells ( $\mathrm{T}$ lymphoma cell) (table 2).

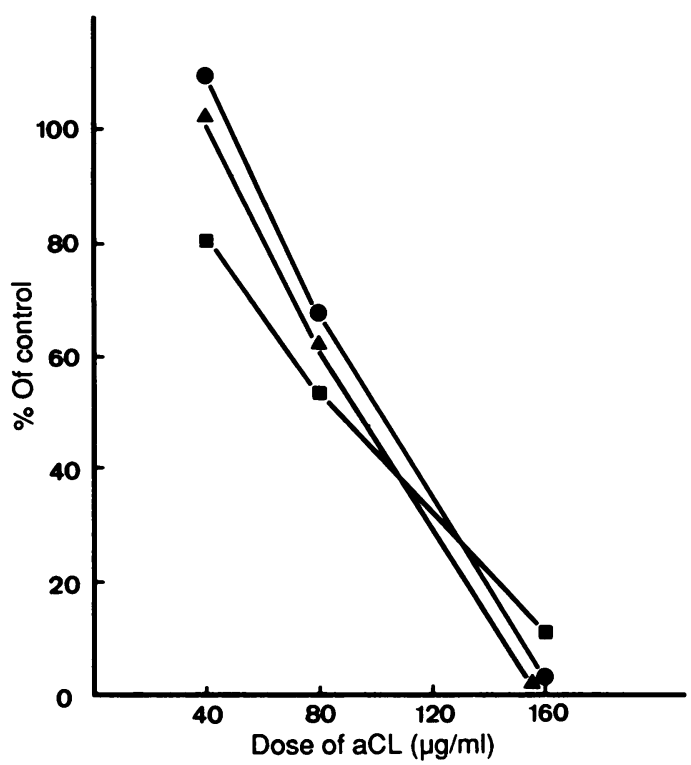

Figure 3 Dose dependent effect of anticardiolipin antibodies $(a C L)$ on phytohaemagglutinin induced $\left[{ }^{3} \mathrm{H}\right]-$ thymidine $\left[{ }^{3} \mathrm{H}-\mathrm{TdR}\right]$ incorporation in human mononuclear cells derived from three different subjects in three day old cultures. The percentage of control was calculated by the counts per minute (cpm) of phytohaemagglutinin stimulated mononuclear cells in the presence of anticardiolipin antibodies divided by the cpm without addition of anticardiolipin antibodies.

Table I Effects of sodium iodide on phytohaemagglutinin and pokeweed mitogen induced $\left[{ }^{3} H\right]$ thymidine incorporation in mononuclear cells in three day old cultures

\begin{tabular}{|c|c|c|}
\hline \multirow{2}{*}{$\begin{array}{l}\text { Concentration of } \\
\text { sodium iodide ( } \mathrm{mol} / \mathrm{l})\end{array}$} & \multicolumn{2}{|c|}{$\left[{ }^{3} \mathrm{H}\right]$ Thymidine incorporation (cpm) } \\
\hline & $\begin{array}{l}\text { Phytohaemagglutinin } \\
(2 \mu g / m l)\end{array}$ & $\begin{array}{l}\text { Pokeweed mitogen } \\
(10 \mu \mathrm{g} / \mathrm{ml})\end{array}$ \\
\hline $\begin{array}{l}0 \\
10^{-6} \\
10^{-4} \\
10^{-2}\end{array}$ & $\begin{array}{ll}61 & 634 \\
64 & 064 \\
62 & 644 \\
66 & 358\end{array}$ & $\begin{array}{l}7818 \\
7773 \\
7598 \\
8561\end{array}$ \\
\hline
\end{tabular}


Table 2 Effects of anticardiolipin antibodies ( $a C L)$ on the proliferation of WI-L2 and furkat cell lines in three day old cultures

\begin{tabular}{|c|c|c|}
\hline & \multicolumn{2}{|c|}{$\left[{ }^{3} \mathrm{H}\right]$ Thymidine incorporation (cpm) } \\
\hline & $\begin{array}{l}\text { WI-L2 } \\
\left(5 \times 10^{4} \text { cells/well }\right)\end{array}$ & $\begin{array}{l}\text { furkat } \\
\left(5 \times 10^{4} \text { cells/well }\right)\end{array}$ \\
\hline $\begin{array}{l}\text { Experiment } 1 \\
\text { Medium } \\
\text { Human IgG } \\
(160 \mu g / m l) \\
\operatorname{aCL}(160 \mu \mathrm{g} / \mathrm{ml})\end{array}$ & $\begin{array}{r}298603 \\
284787 \\
174\end{array}$ & $\begin{array}{l}4613 \\
1687\end{array}$ \\
\hline $\begin{array}{l}\text { Experiment } 2 \\
\text { Medium } \\
\text { Human IgG } \\
(160 \mu \mathrm{g} / \mathrm{ml}) \\
\mathrm{aCL}(160 \mu \mathrm{g} / \mathrm{ml})\end{array}$ & $\begin{array}{r}334584 \\
341351 \\
2876\end{array}$ & $\begin{array}{r}6415 \\
997\end{array}$ \\
\hline
\end{tabular}

EFFECT OF ANTICARDIOLIPIN ANTIBODIES ON THE CELL CYCLE OF MONONUCLEAR CELLS

Compared with human IgG, anticardiolipin antibodies at a concentration of $160 \mu \mathrm{g} / \mathrm{ml}$ markedly suppressed the synthetic (S), gap 2 (G2), and mitotic (M) phases of the phytohaemagglutinin induced cell cycle of mononuclear cells. Figure 4 shows a typical case.

CHANGES OF LYMPHOCYTE SURFACE MARKERS BY ANTICARDIOLIPIN ANTIBODIES

To determine whether decreased mitogen stimulated $\left[{ }^{3} \mathrm{H}\right]$ thymidine incorporation in mononuclear cells in the presence of anticardio-

Table 3 Effects of anticardiolipin antibodies ( $a C L$ ) on the percentage of surface markers of phytohaemagglutinin (PHA) stimulated mononuclear cells in three day old cultures

\begin{tabular}{|c|c|c|c|c|c|}
\hline & \multicolumn{4}{|c|}{$\%$ Of mononuclear cells } & \multirow{2}{*}{$\begin{array}{l}C D 41 \\
C D 8\end{array}$} \\
\hline & $C D 3$ & $C D 4$ & CD8 & $I L-2 R t$ & \\
\hline $\begin{array}{l}\text { Experiment } 1 \\
\text { PHA } \\
\text { PHA+human IgG* } \\
\text { PHA+aCL* }\end{array}$ & $\begin{array}{l}74 \cdot 0 \\
76 \cdot 7 \\
56 \cdot 7\end{array}$ & $\begin{array}{l}29 \cdot 4 \\
27 \cdot 0 \\
12 \cdot 5\end{array}$ & $\begin{array}{l}59 \cdot 7 \\
58.6 \\
15.6\end{array}$ & $\begin{array}{l}51 \cdot 0 \\
74.5 \\
28.3\end{array}$ & $\begin{array}{l}0.49 \\
0.46 \\
0.80\end{array}$ \\
\hline $\begin{array}{l}\text { Experiment } 2 \\
\text { PHA } \\
\text { PHA+human IgG } \\
\text { PHA+aCL }\end{array}$ & $\begin{array}{l}69 \cdot 3 \\
60 \cdot 4 \\
47 \cdot 2\end{array}$ & $\begin{array}{l}34 \cdot 3 \\
38 \cdot 2 \\
10 \cdot 1\end{array}$ & $\begin{array}{l}38.2 \\
22.6 \\
10.8\end{array}$ & $\begin{array}{l}45 \cdot 8 \\
35 \cdot 1 \\
25.8\end{array}$ & $\begin{array}{l}0.90 \\
1.69 \\
0.94\end{array}$ \\
\hline $\begin{array}{l}\text { Experiment } 3 \\
\text { PHA } \\
\text { PHA+human IgG } \\
\text { PHA+aCL }\end{array}$ & $\begin{array}{l}79 \cdot 5 \\
77 \cdot 3 \\
72 \cdot 6\end{array}$ & $\begin{array}{l}50.6 \\
50.3 \\
43.4\end{array}$ & $\begin{array}{l}25 \cdot 1 \\
27 \cdot 1 \\
21 \cdot 8\end{array}$ & $\begin{array}{l}19 \cdot 7 \\
19 \cdot 2 \\
14 \cdot 2\end{array}$ & $\begin{array}{l}2.02 \\
1.86 \\
1.99\end{array}$ \\
\hline
\end{tabular}

${ }^{*}$ The concentration of human IgG and of anticardiolipin antibodies was $160 \mu \mathrm{g} / \mathrm{ml}$.

†IL-2R=interleukin 2 receptor.

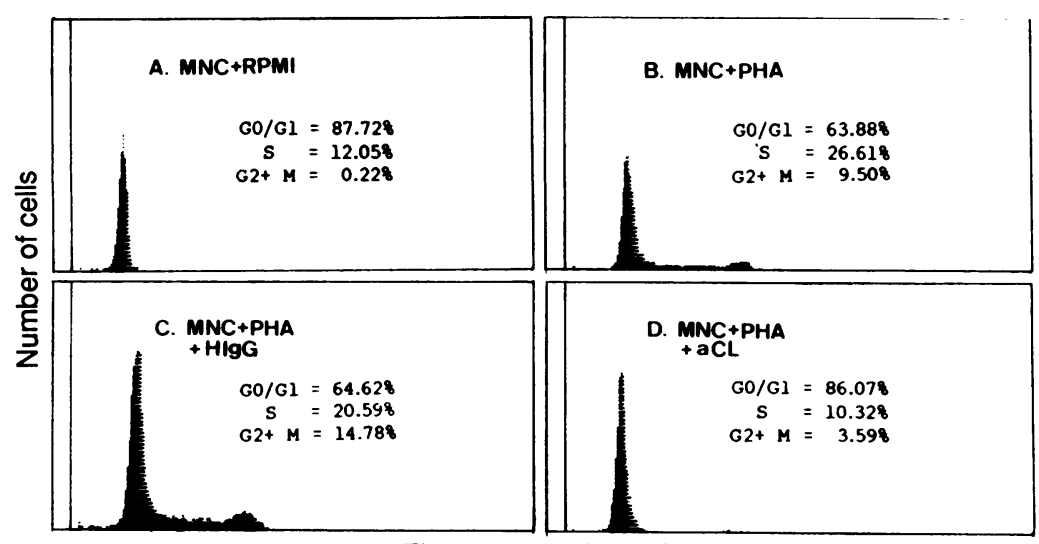

Fluorescence intensity

Figure 4 Effect of anticardiolipin antibodies $(160 \mu \mathrm{g} / \mathrm{ml})$ on the cell cycle of phytohaemagglutinin stimulated human mononuclear cells. MNC= mononuclear cells; PHA=phytohaemagglutinin; $H I g G=$ human IgG; $a C L=$ anticardiolipin antibodies. lipin antibodies changes the $\mathrm{T}$ cell subpopulations or not, the percentages of CD3, CD4, and $\mathrm{CD} 8$ positive lymphocytes in mononuclear cells were measured by flow cytometry. Although the percentages of these three subpopulations were all decreased by anticardiolipin antibodies, the $\mathrm{CD} 4 / \mathrm{CD} 8$ ratio was not changed. In addition, the percentage of interleukin 2 receptor positive cells in phytohaemagglutinin stimulated mononuclear cells was markedly decreased in the presence of anticardiolipin antibodies (table 3). This suggests that anticardiolipin antibodies non-selectively suppress the surface marker expression on mitogen stimulated lymphocytes.

The inhibitory effect of anticardiolipin antibodies on phytohaemagglutinin stimulated mononuclear cell proliferation was further supported by the decreased generation of soluble interleukin 2 receptor in the supernatants (table 4).

SUPPRESSION OF POLYMORPHONUCLEAR LEUCOCYTE PHAGOCYTOSIS BY ANTICARDIOLIPIN ANTIBODIES

Anticardiolipin antibodies, at a concentration greater than $300 \mu \mathrm{g} / \mathrm{ml}$, suppressed the phago-

Table 4 Effects of anticardiolipin antibodies $(a C L)$ on the generation of soluble interleukin 2 receptors $(s I L-2 R)$ in phytohaemagglutinin (PHA) stimulated mononuclear cell supermatants in three day old cultures

\begin{tabular}{|c|c|c|}
\hline & $\begin{array}{l}\left.l^{3} \mathrm{H}\right] \text { Thymidine } \\
\text { incorporation (cpm) }\end{array}$ & $\begin{array}{l}s I L-2 R^{+} \\
(n g / m l)\end{array}$ \\
\hline $\begin{array}{l}\text { Experiment } 1 \\
\text { Medium } \\
\text { PHA } \\
\text { PHA+human IgG* } \\
\text { PHA+aCL }{ }^{*}\end{array}$ & $\begin{array}{r}319 \\
121780 \\
114770 \\
1774\end{array}$ & $\begin{array}{r}<0.50 \\
3.44 \\
7.60 \\
<0.50\end{array}$ \\
\hline $\begin{array}{l}\text { Experiment } 2 \\
\text { Medium } \\
\text { PHA } \\
\text { PHA+human IgG } \\
\text { PHA +aCL }\end{array}$ & $\begin{array}{r}196 \\
34456 \\
36549 \\
3359\end{array}$ & $\begin{array}{r}<0.50 \\
1.26 \\
1.89 \\
<0.50\end{array}$ \\
\hline $\begin{array}{l}\text { Experiment } 3 \\
\text { Medium } \\
\text { PHA } \\
\text { PHA+human IgG } \\
\text { PHA+aCL }\end{array}$ & $\begin{array}{r}204 \\
57347 \\
56943 \\
987\end{array}$ & $\begin{array}{r}<0.50 \\
2.14 \\
2.08 \\
<0.50\end{array}$ \\
\hline
\end{tabular}

${ }^{*}$ The concentration of human IgG and of anticardiolipin anti-

bodies was $160 \mu \mathrm{g} / \mathrm{ml}$.
tThe concentration of sIL-2R in the supernatants was measured tThe concentration of s.
by an ELISA test kit.

Table 5 Effects of anticardiolipin antibodies (aCL) on phagocytosis and on $C 3 b$ and $F_{c}$ receptor expressions on neutrophils*

\begin{tabular}{llll}
\hline \multicolumn{4}{c}{$\%$ Of neutrophils } \\
\cline { 2 - 4 } & Phagocytosis & C3b receptor & Fc receptor \\
\hline Experiment 1 & & & \\
$\quad$ Medium & 35.9 & 73.6 & 53.9 \\
Human IgG† & 41.0 & 53.7 & 50.7 \\
aCL† & 18.5 & 39.4 & 29.4 \\
Experiment 2 & & & \\
Medium & 49.8 & 64.6 & 66.7 \\
Human IgG & 53.7 & 62.9 & 57.4 \\
aCL & 24.6 & 43.6 & 42.3 \\
Experiment 3 & & & \\
Medium & 48.4 & 53.8 & 63.2 \\
Human IgG & 44.6 & 54.7 & 52.5 \\
aCL & 38.2 & 39.4 & 31.4 \\
\hline
\end{tabular}

${ }^{*}$ Neutrophils $\left(2 \times 10^{6} / \mathrm{ml}\right)$ were preincubated with medium human IgG, or anticardiolipin antibodies for one and a hal hours before the measurement of phagocytosis and $\mathrm{C} 3 \mathrm{~b}$ and $\mathrm{Fc}$ receptor expression by flow cytometry.

tThe concentration of human IgG and of anticardiolipin antibodies was $300 \mu \mathrm{g} / \mathrm{ml}$. 
cytic activity of polymorphonuclear leucocytes. The suppression was due to inhibition of $\mathrm{C} 3 \mathrm{~b} / \mathrm{C} 4 \mathrm{~b}$ and $\mathrm{Fc}$ receptor expression on the neutrophils (table 5).

\section{Discussion}

Anticardiolipin antibodies were found in $23-54 \%$ of the patients with SLE. Patients with other collagen vascular diseases, such as rheumatoid arthritis, Sjögren's syndrome, dermatomyositis/polymyositis, ${ }^{16}$ acute and chronic infections, ${ }^{17} 18$ AIDS, ${ }^{19}$ and lymphoproliferative disorders, ${ }^{20}$ contain such antibodies in the blood; they are also found in healthy elderly subjects. ${ }^{21}$ Patients with anticardiolipin antibodies may experience thrombosis in the venous, arterial, placental, or microvascular circulation. ${ }^{22}$ In addition to their effect on the blood coagulation system, there is some evidence that these autoantibodies can bind to certain cells and derange their functions. De Castellarnau et al, ${ }^{23}$ Freyssinet et al, ${ }^{24}$ Carreras et $a l,{ }^{1}$ and Coade $^{25}$ showed that in the presence of lupus anticoagulant the secretion of prostacyclins from vascular endothelial cells or smooth muscle cells was substantially decreased. Furthermore, Khamashta et al showed that purified anticardiolipin antibodies could bind to phosphatidylserine and phosphatidylinositol epitopes expressed on the surface of freeze-thawed platelets or red blood cells. ${ }^{10}$ Schorer et al found that liposome purified anticardiolipin antibodies selectively inhibited prostacyclin release from thrombin activated endothelial cells, but not from nonactivated cells. ${ }^{26}$ The most interesting finding, however, was that of Misra et al, ${ }^{11}$ who showed that affinity purified anticardiolipin antibodies from the serum of a patient with infectious mononucleosis adhered to several cell types, including HEp-2, Molt 4, and phytohaemagglutinin activated peripheral lymphocytes, but did not adhere to the non-stimulated lymphocytes. Apparently, cell activation is necessary for the expression of binding epitopes with anticardiolipin antibodies. The negatively charged phospholipids, such as phosphatidylserine, phosphatidylinositol, or phosphatidylethanolamine, are located primarily in the inner lipid bilayer of the plasma membrane. Once the cells are activated, these phospholipids are expressed on the cell surface and facilitate binding of anticardiolipin antibodies to the membrane. ${ }^{102728}$

In our study we clearly showed that anticardiolipin antibodies from SLE serum samples purified by cardiolipin micelles exerted a suppressive effect on lymphocyte and phagocyte functions in a manner dependent on dose. The anticardiolipin antibodies purified from pooled normal serum samples displayed similar activity also (data not shown). As far as we know this observation has not previously been reported. The inhibitory effect of anticardiolipin antibodies on mitogen induced $\left[{ }^{3} \mathrm{H}\right]$ thymidine incorporation of lymphocytes was not due to $\mathrm{Fc}$ dependent, IgG mediated, non-specific suppression of the immune response ${ }^{29}$ because human IgG $(160 \mu \mathrm{g} / \mathrm{ml})$ had negligible effect. In addition, the $F\left(a b^{\prime}\right)_{2}$ fragment of anticardiolipin antibodies after pepsin digestion retained the complete activity of the intact molecule (data not shown). This inhibition is quite significant because $\mathrm{T}$ cell hypofunction, such as hyporeactivity to delayed hypersensitivity skin test ${ }^{30}$ and phytohaemagglutinin hyporesponsiveness of mononuclear cells, ${ }^{31}$ are commonly found in active SLE. Whether anticardiolipin antibodies can cause $T$ cell hypofunction in vivo is not clear at present because a number of autoantibodies are present in patients with SLE, including antibodies to lymphocytes, dsDNA, or $\beta_{2}$ microglobulin. These antibodies have also been found to suppress the $T$ cell function. ${ }^{15} 32$ In addition, cross reactivity of anticardiolipin antibodies with ssDNA, dsDNA, and cytoskeletal proteins through a common epitope or phosphodiester group has been reported. ${ }^{33}$ Although the anticardiolipin antibodies purified by cardiolipin micelles were contaminated with albumin and other serum proteins (fig 1), as reported by Schorer et al, ${ }^{26}$ inhibition by these proteins was unlikely as larger quantities of similar proteins were already present in the $10 \%$ fetal bovine serum in RPMI-1640 medium. How anticardiolipin antibodies suppress the mitogen induced lymphocyte proliferation is still not clear. Nevertheless, the interleukin 2 receptors on lymphocytes (table 3 ) and the soluble interleukin 2 receptors (table 4 ) in the culture supernatant were remarkably diminished in the presence of anticardiolipin antibodies. It is conceivable that these changes are the result of diminished interleukin 2 production by type 1 helper T lymphocytes.

Another interesting observation in this study was that anticardiolipin antibodies suppressed $\mathrm{C} 3 \mathrm{~b}$ and Fc receptor expressions on polymorphonuclear leucocytes which might be responsible for defective phagocytosis of the cells (table 5). In our previous study ${ }^{15}$ we found that the phagocytosis of polymorphonuclear leucocytes was defective in patients with active SLE. Possibly, the release of many inflammatory mediators is diminished in SLE as a consequence of decreased interleukin 2 production in the presence of anticardiolipin antibodies. Tumour necrosis factor $\alpha$ is a potent stimulant for polymorphonuclear leucocytes and can also stimulate vascular endothelial cells to promote transendothelial neutrophil passage. ${ }^{34} 35$ Once tumour necrosis factor $\alpha$ production is decreased owing to interleukin 2 deficiency, abnormal polymorphonuclear leucocyte functions can be noted. ${ }^{36}$ Another possibility is that the binding of anticardiolipin antibodies to polymorphonuclear leucocyte membrane interferes with $\mathrm{C} 3 \mathrm{~b}$ and IgG Fc receptor expressions and subsequently perturbs the membrane phagocytic activity. This perturbation may occur through the phosphatidylinositol-protein kinase C system because this system plays an important part in the signal transduction of cell activation and proliferation. ${ }^{38} 39$ Whether the defective membrane receptor expression after binding of anticardiolipin antibodies is caused by contracted intracellular receptor pool or impaired translocation of intracellular receptors to cell surface is not clear. Measurement of creatine kinase, 
intracellular $\left[\mathrm{Ca}^{2+}\right] \mathrm{i}$, phospholipid metabolites, and intracellular cAMP and CGMP is necessary to confirm this possibility. In conclusion, our results suggest that anticardiolipin antibodies can exert inhibitory effects on the functions of lymphocytes and neutrophils by non-specific binding to the cell membrane. The significance of this newly found biological activity of anticardiolipin antibodies in patients with SLE needs further investigation.

We thank Miss Whu-Mei Lin and Miss Lina Lin for their technical assistance, and Miss Chun-Shia Chong for typing the echnical assistance, and Miss Chun-Shia Chong for typing the manuscript. This work is supported by grants from the National Academia Sinica, Republic of China.

1 Carreras L O, Defreyn G, Machin S J. Arterial thrombosis, intrauterine death and lupus anticoagulant: detection of immunoglobulin interfering with prostacyclin formation. Lancet 1981; i: $244-6$.

2 Hughes G R V. Thrombosis, abortion, cerebral disease and the lupus anticoagulant. $B M \mathcal{F}$ 1983; 287: 1088-9.

3 Harris E N, Gharavi A E, Asherson R A. Cerebral infarction in systemic lupus: association with anticardiolipin antibodies. Clin Exp Rheumatol 1984; 2: 47-51.

4 Hamsten A, Norberg R, Bjorkholm M, DeFaire U, Holm G. Antibodies to cardiolipin in young survivors of myocardial infarction: an association with recurrent cardiovascular events. Lancet 1986; i: 113-5.

5 Derue G, Englert H J, Harris E N. Fetal loss in systemic lupus: association with anti-cardiolipin antibodies. $\mathcal{F} \mathrm{Obstet}$ lupus: association with anti-cardiolipin
Gynecol Neonatal Nurs 1985; 2: 207-9.

6 Alarcon-Segovia D, Cardiel M H, Reyes E. Anti-phospholipid arterial vasculopathy. $\mathcal{F}$ Rheumatol 1989 ; 16: 762-7.

7 Bowie E J W, Thompson J H Jr, Pascuzzi C A, Owen C A Jr. Thrombosis in systemic lupus erythematosus despite circulating anticoagulants. $\mathcal{f}$ Lab Clin Med 1963; 62: 416-30.

8 Harris E N, Asherson R A, Gharavi A E, Morgan S H, Derue G, Hughes G R V. Thrombocytopenia in SLE and related autoimmune disorders: association with anticardiolipin antibody. Br f Haematol 1985; 59: 227-30.

9 Deleze M, Alarcon-Segovia D, Oria C V, et al. Hemocytopenia in systemic lupus erythematosus: relationship to antiin systemic lupus erythematosus: relationship to anti-

10 Khamashta M A, Harris E N, Gharavi A E, et al. Immune mediated mechanism for thrombosis: antiphospholipid mediated mechanism for thrombosis: antiphospholipid antibody binding

11 Misra R, Venables P J W, Plater-Zyberk C, Watkins P F, Maini $R$ N. Anticardiolipin antibodies in infectious mononucleosis react with the membrane of activated lymphocytes. Clin Exp Immunol 1989; 75: 35-40.

12 Tan E M, Cohen A S, Fries J F, et al. The 1982 revised criteria for the classification of systemic lupus erythematosus. Arthritis Rheum 1982; 25: 1271-7.

13 Harris E N, Gharavi A E, Tincani A, et al. Affinity purified anti-cardiolipin and anti-DNA antibodies. $\mathcal{F}$ Clin Lab Immunol 1985; 17: 155-62.

14 Loizou S, McCrea J D, Rudge A C, Reynolds R, Boyle C C, Harris E N. Measurement of anti-cardiolipin antibodies by an enzyme-linked immunosorbent assay (ELISA): standardization and quan

15 Yu C L, Chang K L, Chiu C C, Chiang B N, Han S H, Wang $S$ R. Defective phagocytosis, decreased tumor necrosis factor- $\alpha$ production, and lymphocyte hyporesponsiveness predispose patients with systemic lupus erythematosus to infections. Scand $\mathcal{F}$ Rheumatol 1989; 18: 97-105.

16 Buchanan R R C, Wardlaw J R, Riglar A G, Little John G O, Miller M H. Antiphospholipid antibodies in the connective tissue diseases: their relation to the antiphospholipid syndrome and torme truste disease. if Kheumatol 1989; 16: 757-61.

17 Colaco C B, Male D K. Anti-phospholipid antibodies in syphilis and a thrombotic subset of SLE: distinct profiles of epitope specificity. Clin Exp Immunol 1985; 59: 449-56.

18 Vaarala O, Palosuo T, Kleemola M, Aho K. Anticardiolipin response in acute infections. Clin Immunol Immunopathol 1986; 41: 8-15

19 Bloom E J, Abrams D I, Rodgers G. Lupus anticoagulant in the acquired immunodeficiency syndrome. FAMA 1986; 256: $491-3$.

20 Gastineau D A, Kazmier F J, Nichols W L, Bowie E J W Lupus anticoagulant: an analysis of the clinical and laboratory features of 219 cases. Am $\mathcal{7}$ Hematol 1985; 19: 265-75.

21 Fields R A, Toubbeh H, Searles R P, Bankhurst A D. The prevalence of anticardiolipin antibodies in a healthy elderly population and its association with antinuclear antibodies. f Rheumatol 1989; 16: 623-5.

22 Lie J T. Vasculopathy in the antiphospholipid syndrome: thrombosis or vasculitis, or both? F Rheumatol 1989; 16: $713-5$.

23 De Castellarnau C, Vila L, Sancho $M$ J, Borrell M, Fontcuberta J, Rutllant $M$ L. Lupus anticoagulant, recurrent abortion, and prostacyclin production by cultured smooth muscle cells. Lancet 1983; ii: 1137-8.

24 Freyssinet J M, Wiesel M L, Gauchy J, Boneu B, Cazenave J P. An IgM lupus anticoagulant that neutralizes the enhancing effect of phospholipid on purified endothelial thrombomodulin activity-a mechanism for thrombosis Thromb Haemost 1986; 55: 309-13.

25 Coade S B. Endothelial prostacyclin release in systemic lupus erythematosus. Thromb Haemost.1989; 61: 97-102.

26 Schorer A E, Wickham N W R, Watson K V. Lupus anticoagulant induces a selective defect in thrombinmediated endothelial prostacyclin release and platelet mediated endothelial prostacyclin release and

27 Gordesky S E, Marinetti G V. The asymmetric arrangement of phospholipids in the human erythrocyte membrane. Biochem Biophys Res Commun 1973; 50: 1027-31.

28 Schick P K, Kurica K B, Chacko G K. Location of phosphatidylethanolamine and phosphatidylserine in the human platelet plasma membrane. 7 Clin Invest 1976; 57 : $1221-6$.

29 Sinclair N R S. Regulation of the immune response. I. Reduction in ability of specific antibody to inhibit long lasting IgG immunological priming after removal of the $\mathrm{Fc}$ fragment. F Exp Med 1969; 129: 1183-201

30 Horwitz D A. Impaired delayed hypersensitivity in systemic lupus erythematosus. Arthritis Rheum 1972; 15: 353-9.

31 Utsinger P D, Yount W J. Phytohemagglutinin response in systemic lupus erythematosus: reconstitution experiments using highly purified lymphocyte subpopulations and using highly purified lymphocyte subpop
monocytes. $\mathcal{F}$ Clin Invest 1977; 60: 628-38.

monocytes. F Clin Invest 1977; 60: 628-38. microglobulin antibodies in systemic lupus erythematosus microglobulin antibodies in systemic lupus erythematosus and ankylosing spondylitis: effects on in

33 Ichikawa K, Shimada K, Nawata Y, et al. Monoclonal hyikawa K, Shimada K, Nawata Y, et al. Monoclonal
hybridoma anti-cardiolipin antibodies from SLE mice. Clin Exp Immunol 1988; 74: 110-4.

34 Moser R, Schleiffenbaum B, Groscurth P, Fehr J. Interleukin 1 and tumor necrosis factor stimulate human vascular endothelial cells to promote transendothelial neutrophil passage. $\mathcal{F}$ Clin Invest 1989; 83: 444-55.

35 Schleiffenbaum B, Fehr J. The tumor necrosis factor receptor and human neutrophil function: deactivation and crossdeactivation of tumor necrosis factor-induced neutrophil responses by receptor down-regulation. $\mathcal{F}$ Clin Invest 1990 ; 86: 184-95.

36 Schleiffenbaum B, Moser R, Fehr J. A defect in chemotaxis from interleukin 2. N Engl f Med 1990; 323: 682-3.

37 Staples P J, Gerding D N, Decker J L, Gordon R S Jr. Incidence of infection in systemic lupus erythematosus. Arthritis Rheum 1974; 17: 1-10.

38 Takai Y, Kishimoto A, Iwasa Y, Kawahara Y, Mori T, Nishizuka Y. Calcium-dependent activation of a multifunctional protein kinase by membrane phospholipids. 7 Biol Chem 1979; 254: 3692-5.

39 Isakov N, Altman A. Human T lymphocyte activation by umor promoters: role of protein kinase C. F Immunol 1987; 138: $3100-7$ 